\title{
Inhibition of Host Protein Synthesis During Infection of Escherichia coli by Bacteriophage T4
}

\author{
II. Induction of Host Messenger Ribonucleic Acid and Its \\ Exclusion from Polysomes
}

\author{
DAVID KENNELL \\ Department of Microbiology, Washington University School of Medicine, St. Louis, Missouri 63110
}

Received for publication 26 February 1970

\begin{abstract}
Two gene clusters on the Escherichia coli chromosome were induced at early times after T4 infection when $>99 \%$ of the cells were infected: the lactose (lac) operon and prophage $\lambda$. Their messenger ribonucleic acid (mRNA) was detected by hybridization to $\phi 80 \mathrm{~d}$ lac deoxyribonucleic acid (DNA) and $\lambda$ DNA, respectively. Synthesis of host mRNA could be initiated during the first few minutes after T4 infection, although no $\beta$-galactosidase activity could be detected. Hybridization analyses of selected fractions from sucrose gradients revealed that most of this lac mRNA induced at very early times of $\mathrm{T} 4$ infection was not associated with ribosomes. In contrast, virtually all lac mRNA in uninfected bacteria was associated with polysomes. This exclusion affected all host mRNA; about $70 \%$ of $E$. coli ${ }^{3} \mathrm{H}$-mRNA, labeled from 2 to $3 \mathrm{~min}$ after T4 infection, was excluded from polysomes. Infection even reduced the yield of $\beta$-galactosidase from lac mRNA induced before infection. Gradients from rifampicin-inhibited cells showed the normal growth of lac mRNA polysomes; in contrast, T4 infection prevented growth of the preinduced lac polysomes. It is concluded that T4 infection interferes within seconds with the reassociation of ribosomes to host mRNA.
\end{abstract}

Infection of Escherichia coli by certain viruses such as the $T$-even phages causes an immediate block in the induction of host-specific enzymes $(3,4,26,32)$. This inhibition has generally been attributed to a sudden decline in host nucleic acid synthesis $(6,15,30,37)$. However, by using improved detection procedures, it was concluded that measurable host ribonucleic acid (RNA) is synthesized for several minutes after infection $(21,25)$; this RNA appears to contain stable and messenger RNA (mRNA) in normal proportions (21). The relationship of this host RNA synthesis to the failure to form host proteins is investigated in this paper to further our understanding of the mechanism of "takeover" of an infected cell by these viruses.

Synthesis of bacterial mRNA during infection could represent transcription of one or both of two classes of molecules: mRNA initiated before infection and completed in the first minutes of infection or molecules initiated as well as transcribed only after infection. Since it is probable that transcription of long operons requires min- utes $(2,27,29,40)$, the former class cannot be excluded without more information regarding the size distribution of $E$. coli mRNA. However, the capacity to initiate mRNA during infection can be measured by inducing a host gene whose RNA product can be detected by hydridization to its complementary deoxyribonucleic acid (DNA) strand. We have estimated RNA synthesis from two inducible gene clusters: RNA induced from the lactose operon (lac mRNA), detected by hybridization to $\phi 80 \mathrm{~d} l a c$ DNA, and RNA induced from the resident prophage $\lambda$, detected with $\lambda$ DNA. In both cases, significant amounts of new mRNA can be induced at times when the infection is complete as judged by other criteria.

However, this induced lac mRNA, as well as most host mRNA, appears to be excluded from polysomes. The results suggest that infection interferes immediately with the association of ribosomes with host mRNA and that this effect can account for the very early inhibition of enzyme induction. 


\section{MATERIALS AND METHODS}

Bacteria, phage, and growth conditions. For lac mRNA induction studies, $E$. coli $\mathrm{K}-12$ was the same strain used in the initial study (21). It is not infected by $R 17$ phage, suggesting an $F^{-}$phenotype. It was grown at $37 \mathrm{C}$ in an inorganic salts medium (23) supplemented with either glucose $(0.2 \%)$ or a mixture of amino acids $(1 \%)$ derived from a hydrolysate of vitamin-free casein (amino acids; Difco) or amino acids plus glycerol $(0.2 \%)$. The mass doubling times were 45,56 , and $35 \mathrm{~min}$, respectively, in each of the above media. Bacteriophage T4B was used in all experiments. L-Tryptophan was present at about 10 $\mu \mathrm{g} / \mathrm{ml}$ at the time of infection.

DNA, enriched for the lac operon, was derived from the double lysogen of $E$. coli CA5004 ( HfrH lac deletion $\mathrm{X74}, \mathrm{B}_{1}^{-} \mathbf{T}_{1,5}^{\mathrm{R}}$ ) that contains $\lambda \mathrm{CI}_{857} \mathrm{~h}^{80}$ plus the defective hybrid $\phi 80$ phage containing $\lambda \mathrm{CI}_{857} \mathrm{lac}^{+}$. Both $\phi 80$ hybrid phages carry the heat-inducible $\mathrm{CI}$ region of $\lambda\left(\mathrm{CI}_{857}\right)$ and induction yields a mixed burst. This strain can be induced to synthesize $\beta$-galactosidase (EC 3.2.1.23) and $\beta$-galactoside transacetylase (EC 2.3.1.18), thus showing that it contains the entire lac operon in the defective phage. CA5004 was kindly supplied by Helen Revel, Department of Biology, Massachusetts Institute of Technology, from the collection of Ethan Signer of that department.

For $\lambda$ induction studies, $\lambda \mathrm{CI}_{857}$ ind $^{+}, E$. coli 594 $\left(F^{-}, S^{R}\right.$ derivative of $W 3350$ that we found to be $\mathrm{lac}^{-}$), and $E$. coli $\mathrm{Y} 10$ (HfrH, leu-) were from William Sly, Division of Medical Genetics; E. coli AB301-1 (Hfr, met $^{-}$) was from David Apirion of this department. $\mathrm{CI}_{857}$ ind $^{+}$lysogens of these strains were made by plating survivors of infection at $30 \mathrm{C}$ and testing for immunity to $\lambda$ infection.

Bacteria were grown at $30 \mathrm{C}$ in the above inorganic salts glucose medium plus required amino acid. To induce the prophage, cultures were brought to $40 \mathrm{C}$ by transfer to a shaking water bath at $40 \mathrm{C}$. The induction of $\lambda$ plaque-forming units (PFU) during T4 infection was estimated on $\mathrm{K}-12 / 4$ indicator cells. Rabbit antiserum to $\lambda$ was added to cultures $30 \mathrm{~min}$ before induction to inactivate free $\lambda$ (about $1 \%$ of the cell count in these cultures). The antiserum, a pool from several rabbits, was prepared by John Courtney of this department and has $\mathrm{K}$ values exceeding 100 .

Preparation of phage stock. $E$. coli lysogens of $\lambda$ $\mathrm{CI}_{857}$ ind $^{+}$or $\mathrm{CA} 5004$ were grown at $30 \mathrm{C}$ in 40 liters of broth. When at about $5 \times 10^{8}$ cells $/ \mathrm{ml}$, they were induced by bringing the temperature to $42 \mathrm{C}$ for 12 min. After $2 \mathrm{hr}$ at $33 \mathrm{C}$, the turbidity had decreased about fivefold. The culture was then chilled and centrifuged through Sharples centrifuges to remove unlysed cells and debris. The supernatant phage titer was estimated, and, if $>2 \times 10^{10} / \mathrm{ml}$, the phage were concentrated about 200-fold with Carbowax. (The procedure was suggested by Norman Melechen, St. Louis University Medical School.) (i) Solid $\mathrm{NaCl}$ (0.3 $\mathrm{M}$ final concentration) was added and mixed for $1 \mathrm{hr}$. (ii) Dextran sulfate, $80 \mathrm{~g}$, and polyethylene glycol (Carbowax), 2,770 $\mathrm{g}$ in 8 liters of solution, were added and mixed for $1 \mathrm{hr}$. The mixture was allowed to separate by standing for 2 days at $4 \mathrm{C}$. Recovery was $>99 \%$ and the phage were further purified by cycles of slow-fast centrifugation.

Preparation of $\phi 80$ dlac phage. After the centrifugation cycles, the mixed phage liberated by induction of strain CA 5004 were mixed with $\mathrm{CsCl}(1.500 \mathrm{~g} / \mathrm{ml})$ and centrifuged at $68,500 \times g$ in an SW39 Spinco rotor for $30 \mathrm{hr}$. A band of the defective $\phi 80 \mathrm{~d}$ lac phage $(\rho=1.501)$ was clearly resolved from the upper band of the active phage $(\rho=1.485)$. Best separations were achieved by pumping $\mathrm{CsCl}$ out from the top of the gradient while slowly lowering a steel collecting tube. Enrichment of the defective phage was estimated from the absorbancy at $\mathbf{2 6 0} \mathrm{nm}$ per PFU. Enrichments were 3.5 times or more. Thus, if the two phage were present in equal numbers in the mixed lysate, this would indicate about $85 \%$ purity in the final $\phi 80 \mathrm{~d} l a c$ preparation.

Denaturation of DNA. $E$. coli T4 and calf thymus DNA were purified and denatured as described previously (24). DNA from $\lambda$ or $\phi 80 \mathrm{~d} l a c$ were purified by the same procedures. However, because of their greater homogeneity, the smaller phage DNA were brought to $0 \mathrm{C}$ after alkaline denaturation and neutralized at a final concentration of only $2 \mu \mathrm{g} / \mathrm{ml}$ to minimize reannealing before trapping on nitrocellulose filter.

Hybridization of RNA to DNA. The procedures have been described in detail (24). Unless specified otherwise, all reactions were performed with the following amounts of DNA trapped to a filter: $25 \mu \mathrm{g}$ of $\phi 80$ $\mathrm{d} l a c, 50 \mu \mathrm{g}$ of T4, $50 \mu \mathrm{g}$ of $\lambda, 50 \mu \mathrm{g}$ of calf thymus, or $100 \mu \mathrm{g}$ of $E$. coli. Thus, all DNA sites were in excess except for the reaction of $E$. coli RNA to its DNA (22).

Preparation and analyses of lysates containing polysomes. $E$. coli $\mathrm{K}-12$ cells were lysed by the procedure of Godson (9) and centrifuged through 15 to $30 \%$ sucrose made in $0.01 \mathrm{M}$ tris(hydroxymethyl)aminomethane (Tris)-hydrochloride $(p H$ 7.3), 0.01 $\mathrm{M} \mathrm{MgSO}_{4}$, and $0.05 \mathrm{M} \mathrm{KCl}$ or $\mathrm{NaCl}$ as specified in each figure. Centrifugation was $110,000 \times g$ in the S110 swinging bucket rotor of the model B60 International centrifuge. After centrifugation, the contents were collected in fractions by pumping from the bottom through a stainless-steel tube. (This procedure was kindly demonstrated to us by L. Luzzatto in the laboratory of D. Schlessinger.) Usually three gradients were collected simultaneously. Odd-numbered fractions were brought to $5 \%$ trichloroacetic acid, whereas the even-numbered fractions (twice the volume of the odd-numbered) were brought to $0.1 \%$ sodium dodecyl sulfate (SDS) and saved. The dry pellet remaining in the tube was resuspended in buffer containing $0.1 \%$ SDS for analyses.

After the acidified fractions had been plated and counted to show the patterns of radioactive ${ }^{14} \mathrm{C}$ - and ${ }^{3} \mathrm{H}-\mathrm{RNA}$, even-numbered fractions were pooled to give fast, intermediate, and slowly sedimenting polysomes, monosomes, and nonpolysomal material. The pooled fractions were dialyzed overnight against 0.001 м Tris-hydrochloride $(p H$ 7.3) plus $0.001 \mathrm{M}$ $\mathrm{Mg}^{2+}$ to remove sucrose, freeze-dried, and brought to $3 \mathrm{ml}$ with water. From each sample, RNA was purified by the phenol, deoxyribonuclease, and 
Pronase steps used to prepare highly-purified RNA for RNA-DNA hydribization (24).

Rifampicin treatment. Rifampicin (gift of David Apirion of this department) was prepared fresh at $5 \mathrm{mg}$ per $\mathrm{ml}$ of $50 \%$ ethanol. Inhibition was maximal at $200 \mu \mathrm{g} / \mathrm{ml}$ as judged by both ${ }^{3} \mathrm{H}$-uracil incorporation and inhibition of $\beta$-galactosidase induction.

\section{RESULTS}

Extent of infection at the time of induction. Different rates of killing by T4 for different $E$. coli $\mathrm{K}-12$ strains have been observed. The lac mRNA studies were done with a strain that is infected very quickly and in this respect behaves more like E. coli B. Judged by the following criteria, infection was extremely rapid in any of the above media, although it might be somewhat slower in the medium unsupplemented with casein hydrolysate. (i) About $99 \%$ of the cells absorbed $\geq$ one phage particle within $1 \mathrm{~min}(21)$. (ii) There was no detectable synthesis of $\beta$-galactosidase when bacteria were induced and infected simultaneously (reference 21; Fig. 1). (iii) Less

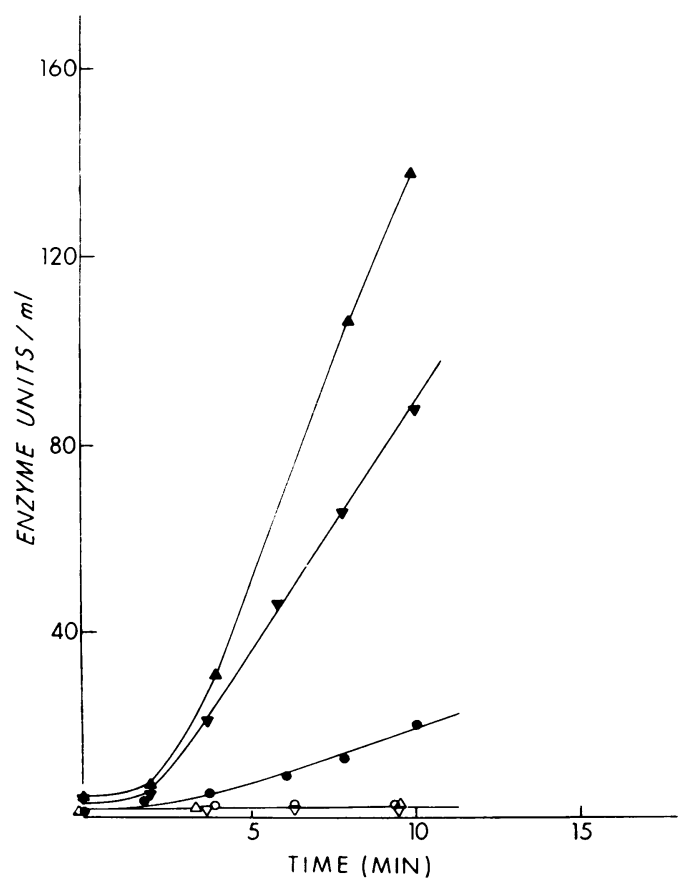

FIG. 1. Induction by isopropyl- $\beta$-D-thiogalactoside of $\beta$-galactosidase in $E$. coli $K-12$ growing in different media in the absence (closed symbols) or in the presence (open symbols) of T4 added simultaneously with inducer at a multiplicity of infection of 10. Inorganic salts plus amino acids (1\% derived from a hydrolysate of casein; $\nabla, \nabla)$, the same plus $0.2 \%$ glycerol $(\mathbf{\Delta}$, $\triangle)$, and inorganic salts plus $0.2 \%$ glucose $(0,0)$. There were $5 \times 10^{8}$ bacteria $/ \mathrm{ml}$ at time zero. than $1 \%$ of the bacteria were viable within 1 to 2 min after infection. Inhibition of $\beta$-galactosidase induction was always measured, as well as killing in most experiments, to be sure that the infection was complete.

Infection is defined as complete at a certain time if events resulting from infection are irreversible. It does not mean that these events occur at the time the infection is complete. For example, the bacteria are not killed until some later time, but, if $99 \%$ cannot produce colonies at $1 \mathrm{~min}$, it means that $99 \%$ are infected irreversibly at 1 min; the dilutions made at this time to measure viability preclude further adsorption (1). Similarly, the complete inhibition of $\beta$-galactosidase synthesis means the absence of the enzyme activity which appears 2 or 3 min after induction of uninfected cells. Since induction $30 \mathrm{sec}$ before infection results in a measurable burst of this activity (21), it means that infection prevents the expression of " $30-\mathrm{sec}$ worth" of normal induced enzyme.

The $\lambda$ induction studies were done with strains that are killed more slowly (with or without prophage) by $\mathrm{T} 4$ than the above strain. Therefore, to ensure that virtually all bacteria were infected when the $\lambda$ mRNA was induced, the bacteria were superinfected with a higher multiplicity at 2 min to infect any cells surviving the initial infection. Under these conditions, very few of the initially infected cells are lysed from without even with such a high multiplicity of infection because of the exclusion of the superinfecting phage (36). The viable cell count and number of bacteria capable of giving a $\lambda$ plaque after T4 infection of $E$. coli $594 \lambda \mathrm{CI}_{857}$ are shown in Fig. 2 . By both criteria, $<1 \%$ of the cells were not infected at $4 \mathrm{~min}$; at this time, the temperature was raised to induce the $\lambda$ prophage.

Induction of lac mRNA during T4 infection. Induction of lac mRNA was measured in different media during T4 infection (Table 1) under conditions in which no $\beta$-galactosidase activity could be detected (Fig. 1). Uninfected cells without inducer (sample 1) had a low but detectable level of lac mRNA which reflects the basal level of enzyme synthesis. The level of lac mRNA increased very rapidly after inducer addition; RNA labeled between 1 and 3 min (sample 2) had almost as much ${ }^{3} \mathrm{H}$-lac RNA as did RNA labeled 12 to $14 \mathrm{~min}$ after induction (sample 3). Induction during T4 infection is shown for samples 4,6 , and 9. In these experiments, RNA was labeled soon after inducer was added (0.5 to 1.5 min). Even at such a short time after induction and at a time when infection was complete, it is clear that a high level of lac RNA could be induced in any of the media.

Induction at later times of infection was not 


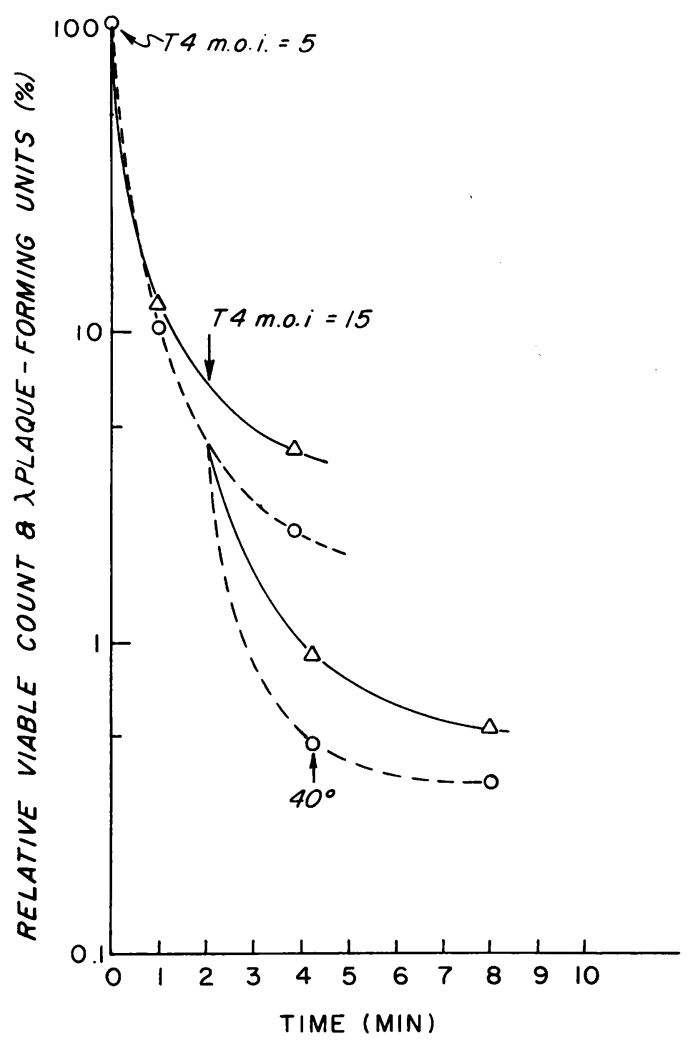

FIG. 2. Effects of T4 infection on the viability of $E$. coli $\mathrm{K}-12594\left(\lambda \mathrm{CI}_{857}\right.$ ind $\left.^{+}\right)$, and its capacity to produce $\lambda$ plaques. Rabbit antiserum against $\lambda$ was added to the cultures 30 min before infection to inactivate free $\lambda$. The lysogen was induced at the times shown by transfer of the growth flask to a water bath at $40 \mathrm{C}$. $\lambda$ PFU were estimated on $K-12 / 4 h$ indicator cells. Symbols: $\triangle, \lambda \mathrm{PFU} / \mathrm{ml}$; O, viable bacteria $/ \mathrm{ml}$.

measured because the level of host mRNA that can be synthesized does decrease progressively with time and thus such measurements become less significant. It should be noted that, although as much as half of the RNA synthesized after 2 or $3 \mathrm{~min}$ of infection is transcribed from the host genome (22), a part of this RNA is presumably composed of long molecules that were initiated just before infection.

Synthesis of $\lambda$ mRNA during T4 infection of a $\lambda$ lysogen. A second system investigated was the synthesis of mRNA by a $\lambda$ prophage that is integrated in the bacterial chromosome (18). Lysogens of the heat-inducible $\lambda \mathrm{CI}_{857}$ ind $^{+}$were selected. Measurements of the levels of $\lambda$ mRNA in this strain during or in the absence of T4 infection are summarized in Table 2 . Infected cells were heat-induced at $4 \mathrm{~min}$ after infection when $>99 \%$ of the bacteria were not viable or capable of producing $\lambda$ plaques (Fig. 2). Noninduced bacteria had a low but measurable amount of $\lambda$ mRNA (cultures 1 and 2); most of this was probably mRNA for the CI immunity and rex region.

The level of $\lambda$ mRNA increased very soon after bringing the culture to $40 \mathrm{C}$; close to $1 \%$ of the RNA labeled from 2 to $3 \mathrm{~min}$ after induction annealed to $\lambda$ DNA (culture 3 ). When the lysogen was induced $4 \mathrm{~min}$ after T4 infection, almost as much of the RNA synthesized from 2 to $3 \mathrm{~min}$ later was $\lambda$-specific (culture 4). In the uninfected bacteria, the $\lambda$-specific RNA increased rapidly with time of induction (culture 5). However, $\lambda$ mRNA synthesis was shut-off late in T4 infection (culture 6); this was expected since there is very little, if any, E. coli RNA synthesized at these late times after infection (21). This could explain why no $\lambda$ mRNA synthesis was detected during T4 infection in an earlier study; the RNA was labeled 7 to $8 \mathrm{~min}$ after infection (14).

The same measurements were made with two other lysogens (AB301- $\lambda \mathrm{CI}_{857}$ and $\mathrm{Y} 10-\lambda \mathrm{CI}_{857}$ ) with similar results. The significant conclusion is that almost normal amounts of $\lambda$ mRNA can be induced at an early time after T4 infection, but it is at a time nonetheless when virtually all of the bacteria are irreversibly infected. It is probable that the $\lambda$ genome is still integrated at this early time since excision requires the protein products of at least the int $(8,10)$ and xis $(11)$ genes of $\lambda$. Thus, in this respect, the induction of $\lambda$ mRNA is comparable to induction of a specific host RNA.

Exclusion of newly synthesized E. coli RNA from polysomes during T4 infection. An effort was made to determine why host mRNA induced during infection was not translated. The association of ribosomes with host mRNA was examined in polysome gradients. Figure 3 shows the sedimentation of stable and newly synthesized RNA components from uninfected bacteria. About $60 \%$ of the stable RNA $(70 \%$ of the ribosomal material) sedimented in the polysome region with about $50 \%$ of the newly synthesized RNA $\left({ }^{3} \mathrm{H}\right.$ RNA). This value (50\%) corresponds to the fraction of newly synthesized RNA that is mRNA (22), indicating that the total mRNA is in polysomes (28).

The distribution of newly synthesized $E$. coli RNA was very different in T4-infected cells. RNA was labeled from 2 to $3 \mathrm{~min}$ after infection; at this time, 30 to $40 \%$ of the exogenous uracil is entering host RNA while the remainder is incorporated into T4 RNA (21). The fraction of total $E$. coli and T4 ${ }^{3} \mathrm{H}-\mathrm{RNA}$ that is present in each region of a gradient is shown in Fig. 4. Only $15 \%$ 
TABLE 1. Induction of lac $m R N A$ during T4 infection

\begin{tabular}{|c|c|c|c|c|c|c|c|c|c|c|}
\hline \multicolumn{5}{|c|}{ Culture conditions ${ }^{a}$} & \multicolumn{6}{|c|}{ Per cent of ${ }^{3} \mathrm{H}-\mathrm{RNA}$ hybridized to given $\mathrm{DNA}^{b}$} \\
\hline Sample & $\begin{array}{c}\text { Growth } \\
\text { me- } \\
\text { dium }^{c}\end{array}$ & $\mathrm{~T} 4$ & Inducer & ${ }^{3} \mathrm{H}$-uracil & E. coli & $\mathrm{T} 4$ & lac & Calf & $\lambda$ & Blank \\
\hline $\begin{array}{r}1 \\
2 \\
3 \\
4 \\
5 \\
6 \\
7 \\
8 \\
9 \\
10\end{array}$ & $\begin{array}{l}\text { A } \\
\text { A } \\
\text { A } \\
\text { A } \\
\text { B } \\
\text { B } \\
\text { B } \\
\text { C } \\
\text { C } \\
\text { C }\end{array}$ & $\begin{array}{c}0 \\
0 \\
0.5-1.0 \\
0 \\
0\end{array}$ & $\begin{array}{l}\min \\
0 \\
0 \\
0.5 \\
0 \\
0.5 \\
0 \\
0 \\
0.5 \\
-\end{array}$ & $\begin{array}{c}\text { min } \\
0-2 \\
1-3 \\
12-14 \\
1-2 \\
0.5-1.5 \\
1-2 \\
0 \\
0.5-1.5 \\
1-2 \\
1-2\end{array}$ & $\begin{array}{c}33.1 \\
9.82 \\
22.0 \\
23.3 \\
14.0\end{array}$ & $\begin{array}{c}0.026 \\
0.066 \\
0.035 \\
\\
0.041 \\
35.0 \\
1.15 \\
0.080 \\
37.2 \\
24.0\end{array}$ & $\begin{array}{l}0.082 \\
1.91 \\
2.33 \\
0.41 \\
0.70 \\
0.47 \\
0.26 \\
0.35 \\
0.25 \\
0.084\end{array}$ & $\begin{array}{l}0.018 \\
0.036 \\
\\
0.047 \\
0.074 \\
0.15 \\
0.15 \\
0.060 \\
0.087 \\
0.03\end{array}$ & $\begin{array}{l}0.087 \\
0.12\end{array}$ & 0.040 \\
\hline
\end{tabular}

a Growth was terminated by pouring bacteria on 3 volumes of crushed ice with $0.01 \mathrm{M}$ cyanide. In sample 4, at 1.2 and $2.5 \mathrm{~min}$, the viable counts were 0.5 and $0.08 \%$, respectively, of that at zero time. Viable counts were not made in sample 6 . In samples 4,6 , and 9 , there was no detectable induction of $\beta$-galactosidase.

${ }^{b}$ The percentages given were not normalized so that the maximum values attainable in the hybridization reaction (about $75 \%$ ) would be $100 \%$. These values represent averages of several determinations made over a range of RNA/DNA inputs (about 0.01 to 1 ). In this range, the T4 and $\lambda$ DNA types are in excess, but the $E$. coli DNA is limiting and the values for $E$. coli DNA should all be multiplied by about two to give expected values with excess DNA in the reaction.

$c$ Growth medium $\mathrm{A}$ is minimal salts medium plus $1 \%$ casein hydrolysate. Medium $\mathrm{B}$ is the same as medium A plus $0.2 \%$ glycerol. Medium $\mathrm{C}$ is minimal salts medium plus $0.2 \%$ glucose.

TABLE 2. Hybridization of $R N A$ from E. coli $594\left(\lambda_{C I_{857}} i^{+}\right)$after the treatments indicated ${ }^{a}$

\begin{tabular}{|c|c|c|c|c|c|c|c|c|}
\hline \multirow{2}{*}{ Culture } & \multicolumn{5}{|c|}{ Time (min) } & \multicolumn{3}{|c|}{ Per cent of ${ }^{3} \mathrm{H}-\mathrm{RNA}$ hybridized ${ }^{b}$} \\
\hline & No $\mathrm{T} 4$ & $\stackrel{\mathrm{T} 4}{(\mathrm{MOI}=6)}$ & $\stackrel{\mathrm{T} 4}{(\mathrm{MOI}=18)}$ & $40 \mathrm{C}$ & ${ }^{3} \mathrm{H}$-uracil ${ }^{c}$ & E. coli & $\mathrm{T} 4$ & $\lambda$ \\
\hline $\begin{array}{l}1 \\
2 \\
3 \\
4 \\
5 \\
6\end{array}$ & $\begin{array}{l}0 \\
0 \\
0\end{array}$ & $\begin{array}{l}0 \\
0\end{array}$ & $\begin{array}{l}2 \\
2 \\
2\end{array}$ & $\begin{array}{l}4 \\
4 \\
4 \\
4\end{array}$ & $\begin{array}{c}0-1 \\
6-7 \\
6-7 \\
6-7 \\
10-11 \\
10-11\end{array}$ & $\begin{array}{r}51.2 \\
2.4 \\
44.1 \\
2.2 \\
50.7 \\
2.7\end{array}$ & $\begin{array}{c}0.02 \\
55.7 \\
0.04 \\
67.8 \\
0.09 \\
61.0\end{array}$ & $\begin{array}{l}0.22 \\
0.22 \\
0.92 \\
0.82 \\
5.92 \\
0.14\end{array}$ \\
\hline
\end{tabular}

${ }^{a}$ Bacteria were grown at $30 \mathrm{C}$ and either infected or not infected with phage T4 [multiplicity of infection $(\mathrm{MOI})=6$ ] at the time defined as zero. Thus, cultures to compare are identified more easily; e.g., cultures 3 and 4 show the results for RNA labeled from 2 to 3 min after raising the temperature to $40 \mathrm{C}$ either with (4) or without (3) prior T4 infection. At the time the temperature was raised to $40 \mathrm{C}$ in the infected cultures $(4 \mathrm{~min})$, the number of viable cells and cells giving $\lambda$ plaques were 0.5 and $0.6 \%$, respectively, of the values at zero time.

$b$ The percentages given were not normalized so that the maximum values attainable in the hybridization reaction (about $75 \%$ ) would be $100 \%$. These values represent averages of several determinations made over a range of RNA/DNA inputs (about 0.01 to 1 ) and after subtraction of the percentage bound to calf thymus DNA (about $0.04 \%$ ). In this range, the T4 and $\lambda$ DNA types are in excess, but the $E$. coli DNA is limiting and the values for $E$. coli DNA should all be multiplied by about two to give expected values with excess DNA in the reaction.

${ }^{c}{ }^{3} \mathrm{H}$-uracil ( $26 \mathrm{Ci} / \mathrm{mmole}$ ) incorporation was terminated by pouring cells on 3 volumes of crushed ice.

of the newly synthesized $E$. coli RNA was associated with polysomes, whereas the remainder was not. In contrast, about 65 to $70 \%$ of the ${ }^{3} \mathrm{H}-\mathrm{T} 4$ RNA sedimented with polysomes.
Since $50 \%$ of the pulse-labeled RNA of the uninfected bacteria sedimented with polysomes (Fig. 3), it can be concluded that at this time of infection $(50-15) / 50 \times 100$ or $70 \%$ of the host 


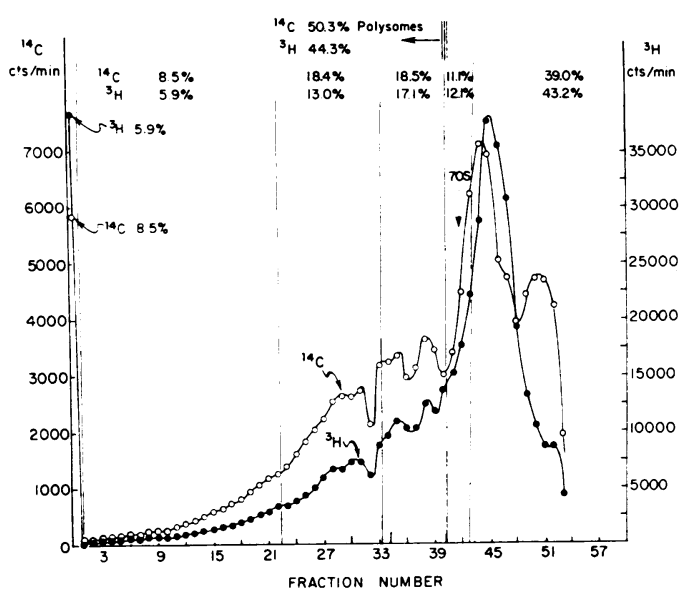

FIG. 3. Distribution of stable and newly synthesized $R N A$ in polysome and nonpolysome fractions of $E$. coli. Bacteria were exposed to a limited amount of ${ }^{14} C$ uracil and grown for at least two generations so that ${ }^{14} \mathrm{C}$ was present only in stable components. At the end of this time $\left(\sim 5 \times 10^{8}\right.$ cells $\left./ \mathrm{ml}\right)$, the cultures were exposed to a 1-min pulse of ${ }^{3} \mathrm{H}$-uracil terminated by pouring the culture on ice. Lysates were prepared and centrifuged through 15 to $30 \%$ sucrose gradients for 2 hr at $2 \mathrm{C}$ in an $\mathrm{S110}$ rotor of the International $B 60$ ultracentrifuge. Fractions were collected and brought to $5 \%$ trichloroacetic acid at $0 \mathrm{C}$, plated, and then counted. ${ }^{14} \mathrm{C}$-stable $\mathrm{RNA}(\mathrm{O}) ;{ }^{3} \mathrm{H}$-pulse-labeled $\mathrm{RNA}$ (O).

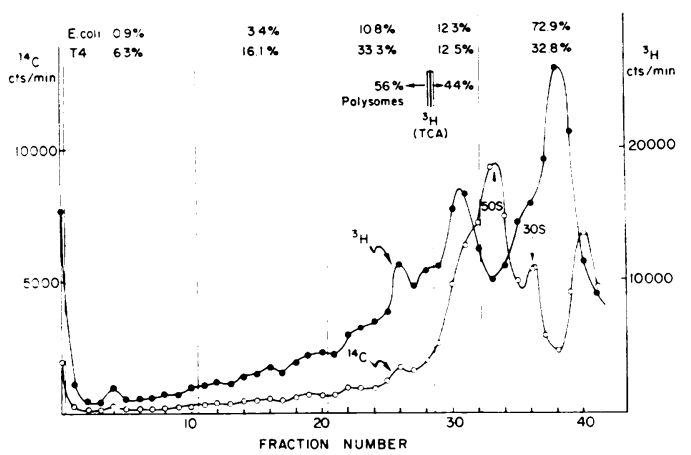

FIG. 4. Distribution of $E$. coli and T4 $R N A$, synthesized during $T 4$ infection, in polysome and nonpolysome fractions of $E$. coli. Bacteria were grown and labeled as outlined in Fig. 3, except that ${ }^{3} \mathrm{H}$-uracil was added 2 min after T4 infection and the culture was brought to $0 \mathrm{C} 0.5 \mathrm{~min}$ later. The lysate was centrifuged for $3.5 \mathrm{hr}$, and alternate one-third fractions were acidified to measure labeled $R N A$ whereas the twothirds fractions were saved. These latter fractions were later pooled into the regions shown, and their RNA was purified for hybridization analyses. The values at the top give the fraction of $E$. coli or of $T 4{ }^{3} \mathrm{H}-\mathrm{RNA}$ that is in a given region; $56 \%$ of the ${ }^{3} \mathrm{H}-\mathrm{RNA}$ was with polysomes. ${ }^{14} \mathrm{C}$-stable $R N A(O),{ }^{3} \mathrm{H}$-pulse-labeled RNA (O).
mRNA is excluded from polysomes. In contrast, only 30 to $35 \%$ of the T4 RNA is not associated with ribosomes.

The same experiment was repeated, but the gradients were centrifuged for a longer time to estimate the sedimentation rates of the host mRNA that is free from ribosomes (Fig. 5). Again, only $15 \%$ of the host ${ }^{3} \mathrm{H}-\mathrm{RNA}$ was in the polysome region, and, of the remainder, close to half sedimented at about $30 S$ and the other half in a separate peak centered at about $16 S$. No further studies have been done to determine if, for instance, the heavier material is $E$. coli mRNA bound to $30 \mathrm{~S}$ ribosomal subunits.

Effect of T4 infection on lac mRNA-polysome complex. Lysates from uninfected bacteria, grown in amino acids medium and pulse-labeled from 30 to $90 \mathrm{sec}$ after induction, are shown in Fig. 6. In this and subsequent figures, the values given in each region show: (a) the ${ }^{3} \mathrm{H}-\mathrm{RNA}$ (per cent of total) in the region, (b) the percentage of the ${ }^{3} \mathrm{H}$ RNA that is lac-specific, and (c) the amount of ${ }^{3} \mathrm{H}$-lac RNA (per cent of total lac RNA). The latter figure is derived from $\left(a_{i}\right)\left(b_{i}\right) / \Sigma\left(a_{i}\right)\left(b_{i}\right)$ $\times 100$. The most important observation is that shortly after induction of uninfected cells little if any lac mRNA can be observed in the top fraction, i.e., in the region of the gradient that is free from complete $70 S$ monosomes. It is probable that synthesis of mRNA does not occur normally in the absence of an associated ribosome.

A parallel gradient from T4-infected cells is shown in Fig. 7. The bacteria were induced at $30 \mathrm{sec}$, and ${ }^{3} \mathrm{H}$-uracil was added from 1 to $2 \mathrm{~min}$

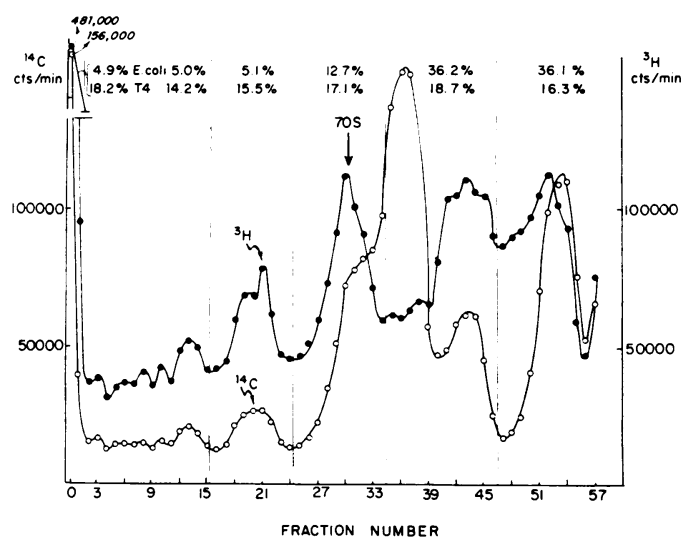

FIG. 5. Distribution of $E$. coli and T4 RNA, synthesized during T4 infection, in polysome and nonpolysome fractions of $E$. coli. Bacteria, grown on a different day, were treated and analyzed exactly as described in Fig. 5, except that centrifugation was for $6 \mathrm{hr} .{ }^{14} \mathrm{C}$-stable RNA (O); ${ }^{3} \mathrm{H}$-pulse-labeled $\mathrm{RNA}$ (O). 


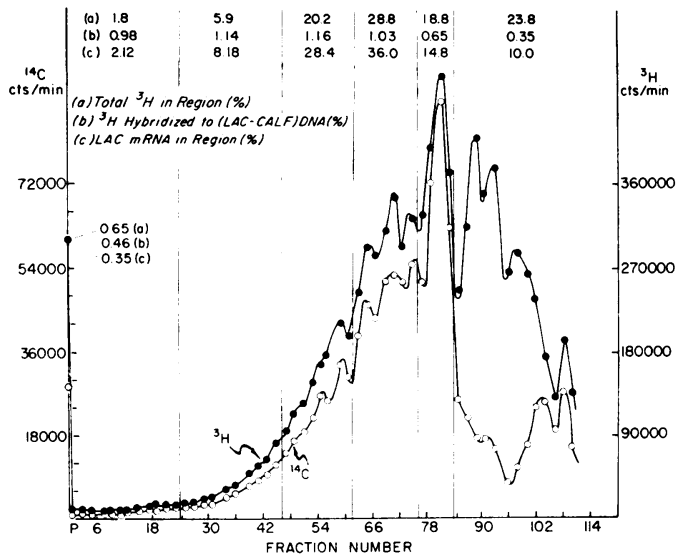

Fig. 6. Distribution of lac $m R N A$ in polysome and nonpolysome fractions of $E$. coli grown in amino acids medium. ${ }^{14}$ C-stable $R N A$ was labeled as described in Fig. 4. Bacteria were induced with isopropyl- $\beta-D-$ thiogalactoside at $5 \times 10^{8} \mathrm{cells} / \mathrm{ml}$ and exposed to ${ }^{3} \mathrm{H}$-uracil $30 \mathrm{sec}$ later. The culture was brought to $0 \mathrm{C}$ at $90 \mathrm{sec}$. Lysates were centrifuged for $3 \mathrm{hr}$, and alternate fractions were acidified for radioactivity measurement or RNA purification (see legend of Fig. 4). The values given in the figure are discussed in the text. ${ }^{14} \mathrm{C}$-stable $R N A(O) ;{ }^{3} \mathrm{H}-\mathrm{RNA}(\mathrm{O})$.

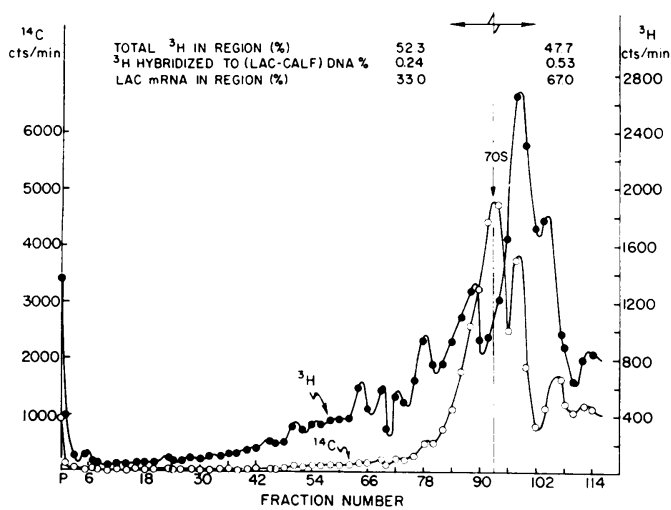

FIG. 7. Distribution of induced lac $m R N A$ in polysome and nonpolysome fractions of T4-infected E. coli grown in amino acids medium. Bacteria were grown, labeled, and analyzed as described in Fig. 6, except that the cells were infected with T4 30 sec before induction with isopropyl- $\beta$-D-thiogalactoside. ${ }^{14} \mathrm{C}$-stable RNA (O); ${ }^{3} \mathrm{H}$-pulse-labeled RNA (O).

after infection. Thus, the infected cultures were labeled for the same period after induction as were the uninfected bacteria. The resulting gradient was divided into only two regions, polysome and nonpolysome, since only limiting amounts of radioactivity could be incorporated during infection in that growth medium. How- ever, this division is adequate to demonstrate that both the specific activity (per cent of ${ }^{3} \mathrm{H}$ hybridized to lac DNA) and the amount of lac mRNA are much higher in the nonpolysome region than in the region of polysomes. About two-thirds of the total ${ }^{3} \mathrm{H}$-lac RNA is not associated with ribosomes.

Similar results were observed when induction and infection occurred in salts-glucose medium (Fig. 8). That some lac mRNA was found in polysomes probably reflects the fact that infection occurred somewhat slower in salts-glucose than in amino acids medium.

Effect of infection on preinduced mRNA. The effects of rifampicin inhibition and phage infection on the translational yield of preinduced lac mRNA have been compared. Since rifampicin inhibits the initiation of RNA synthesis but not continued transcription $(7,38)$, it should affect expression of the lac operon in an identical fashion as does inducer removal (35). However, as
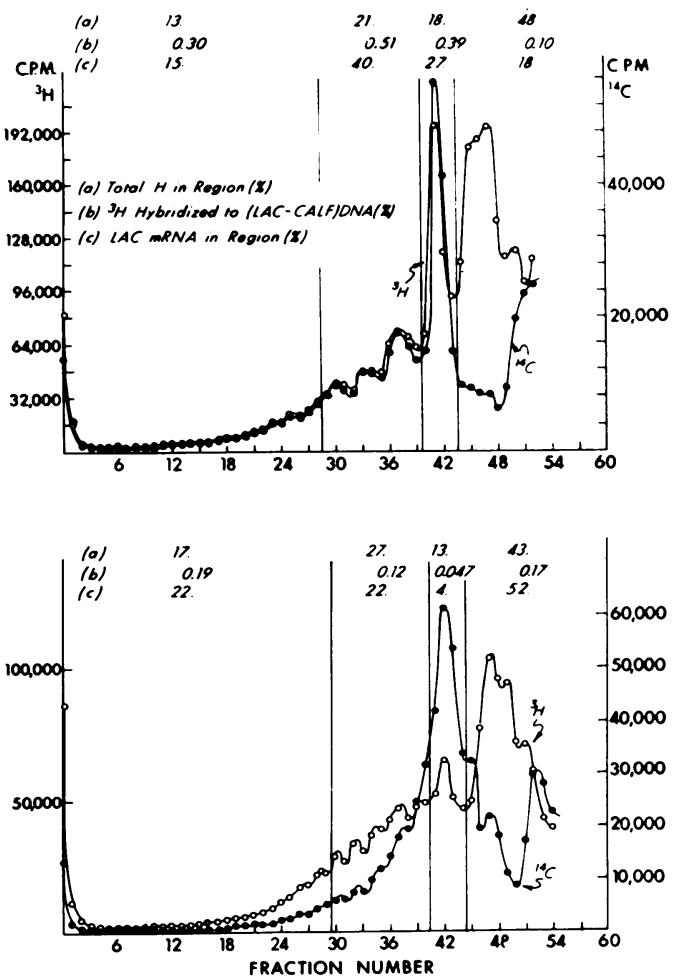

Fig. 8. Distribution of induced lac $m R N A$ in polysome and nonpolysome fractions of uninfected (top) and T4-infected (bottom) E. coli grown in inorganic salts-glucose medium. Bacteria were labeled and analyzed as described in the legends of Fig. 6 (uninfected) and Fig. 7 (infected). ${ }^{14} \mathrm{C}$-stable RNA (O); ${ }^{3} \mathrm{H}$-pulse-labeled $\mathrm{RNA}$ (O). 
opposed to inducer removal, rifampicin affected all operons as well as lac. Rifampicin completely prevented the induction of $\beta$-galactosidase but allowed a "burst" of enzyme synthesis when added very soon after inducer. This burst was significantly higher than that observed when T4 was added after inducer. Thus, as shown in earlier studies $(19,31)$, infection decreases the normal translational yield of the preexisting mRNA; this suggests that infection affects the translation of all host mRNA, including those molecules initiated before T4 adsorption.

We compared the distribution of preinduced lac mRNA on polysomes in T4-infected versus rifampicin-inhibited bacteria. Isopropyl- $\beta$-D-thiogalactoside and ${ }^{3} \mathrm{H}$-uracil were added to each of three parallel cultures at zero time. At $1 \mathrm{~min}, \mathrm{~T} 4$ and unlabeled uracil were added to one culture, rifampicin and unlabeled uracil were added to a second, and unlabeled uracil was added to a third (control). All three were chilled 1 min later. Polysome gradients from the cell lysates are shown in Fig. 9. If we assume that rifampicin prevents new transcriptional initiations whereas T4 prevents or decreases new translational initiations at the $5^{\prime}$ ends of mRNA, several predictions can be made.

(i) There should be an enrichment (percentage of ${ }^{3} \mathrm{H}$ that is lac-specific) for lac mRNA on the polysomes of rifampicin versus control bacteria. (ii) There should be an enrichment for lac mRNA on the polysomes (especially the smallest) of T4infected versus control bacteria. (iii) The total amount of ${ }^{3} \mathrm{H}$-lac mRNA should be significantly lower on polysomes of T4-infected compared to rifampicin-inhibited bacteria.

First, the lac mRNA is very large compared to the bulk of $E$. coli messages $(5,17,34,39)$ and all other types of mRNA are in various phases of synthesis and breakdown; in contrast, all of the lac mRNA had been initiated from 0 min on. Therefore, in rifampicin-treated bacteria, many of the other mRNA types are chased off the polysomes from 1 to 2 min to give an enrichment for lac RNA. This is observed in that the percentage of ${ }^{3} \mathrm{H}$ that is lac-specific is two to three times higher in the rifampicin compared to the control cultures (prediction one).

If no new ribosomes attached to host mRNA in the T4-infected culture, then no new polysomes would develop and polysomes existent at the time of infection would either stay the same size or actually become smaller; if the chase were sufficiently long to complete transcription of the operon and allow the first ribosomes to cycle off the $3^{\prime}$ end, they would become smaller. Furthermore, without ribosomes on the $5^{\prime}$ side of the mRNA to protect it, that side might either be

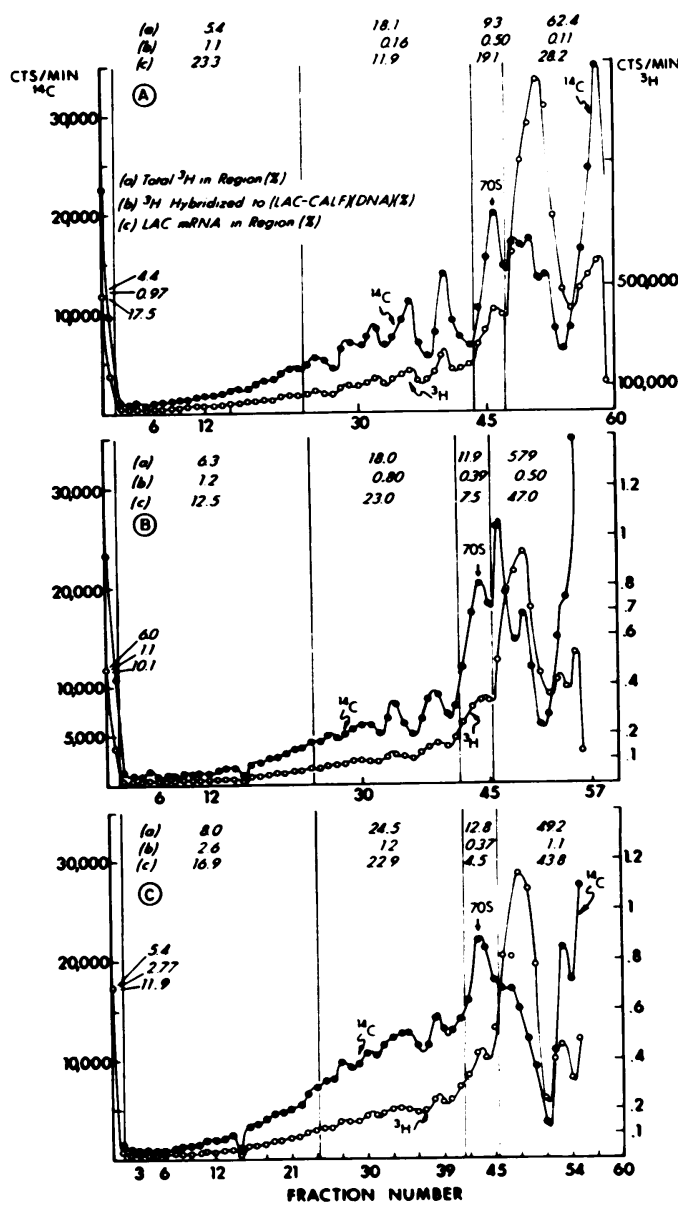

Fig. 9. Distribution of ${ }^{3} \mathrm{H}$-lac $m R N A$ on polysome and nonpolysome fractions of $E$. coli after a "chase" with ${ }^{1} \mathrm{H}$-uracil alone (top), plus T4 (middle), or plus rifampicin (bottom). ${ }^{3} \mathrm{H}$-uracil plus isopropyl- $\beta-D-$ thiogalactoside were added to cultures at zero time. At 1 min, ${ }^{1} \mathrm{H}$-uracil, with or without inhibitor, was added; the cultures were brought to $0 \mathrm{C}$ at $2 \mathrm{~min}$. Stable RNA was labeled as described (Fig. 3). Lysates of the bacteria were analyzed as described in Fig. $6 .{ }^{14} \mathrm{C}$ stable RNA (O); ${ }^{3} \mathrm{H}$-pulse-labeled $\mathrm{RNA}$ (O).

degraded by a $5^{\prime}$ exonuclease or be detached from the polysome by an endonuclease. In the latter case, ${ }^{3} \mathrm{H}$-lac $\mathrm{RNA}$ would appear at the top region of the gradient, and, in fact, there is lac-specific RNA in the nonribosome region. In either case, there would be an enrichment of lac mRNA, especially on the smallest polysomes, since not only will other host mRNA be chased out of these structures but much more lac mRNA will accumulate in polysomes of this size-class because of this inability to grow in size; as shown, the lac mRNA is five times enriched $(0.80 / 0.16)$ in this region (prediction two). 
Finally, if the $5^{\prime}$ sides of the unprotected ${ }^{3} \mathrm{H}$-lac mRNA were attacked by nuclease, the total amount of ${ }^{3} \mathrm{H}$-lac mRNA should be significantly lower on polysomes of T4-infected compared to rifampicin-inhibited bacteria. In the case of the drug-inhibited cells, new ribosomes would be added onto the preinduced lac mRNA; this would protect the $5^{\prime}$ ends to give them a normal lifetime and also to increase their average size up until the initial attack on the $5^{\prime}$ end prevented further ribosomes from attaching. Since the total ${ }^{3} \mathrm{H}$ RNA per milliliter is about the same in both cultures, the amount of ${ }^{3} \mathrm{H}$-lac RNA per region is given by the product of the ${ }^{3} \mathrm{H}$ per region (per cent) and the percentage of ${ }^{3} \mathrm{H}$ that is lac-specific. From this, it can be shown that there is 2.5 times more ${ }^{3} \mathrm{H}$-lac RNA on the two heavy polysome classes of the rifampicin-treated compared to the T4-inhibited bacteria and about twice as much lac mRNA on the total polysome population (prediction three).

\section{DISCUSSION}

The experiments reported in this paper show that the transcription of mRNA from the $E$. coli chromosome can be initiated during the early minutes of T4 infection. However, this mRNA cannot be translated into active enzyme. Thus, the immediate block in the capacity to induce enzymes is not due to inhibition of either transcription or its initiation but to a later step. An effort was made to identify this step.

It was observed that most of the lac mRNA induced during infection did not sediment with the fast-moving polysome structures. That this was not unique to the lac RNA was shown by the fact that about $70 \%$ of the host mRNA synthesized early in infection was excluded from polysomes. Furthermore, lac mRNA induced before infection gave an abnormally low yield of enzyme. This suggested that the immediate effects of infection on translation were not only on mRNA initiated during infection but also on host mRNA that was in the process of being transcribed and translated at the time of infection.

To investigate this possibility, the effects of T4 infection on the translation of preinduced lac mRNA were compared to the effects of rifampicin on its translation. For these studies, rifampicin inhibition was preferable to inducer removal because, like T4 infection, it acted not only on the lac operon but on all bacterial transcriptions, thus allowing a more direct comparison of the distributions of lac mRNA on polysomes in the two cases. Large polysomes were attained when further transcription-initiations were prevented by rifampicin since this inhibitor did not interfere with transcriptions already in progress. However,
T4 infection appeared to prevent preinduced lac mRNA from becoming a part of larger polysome structures.

One interpretation of these results would be that infection greatly reduces the capacity of ribosomes to attach to the $5^{\prime}$ end of host RNA. Such a defect could result from any of a number of causes which would have to be specific to host but not to phage mRNA expression, e.g., (i) release of a $5^{\prime}$ exonuclease that degraded the ends of host mRNA; (ii) some alteration in ribosomes (16; F. L. Smith and R. Haselkorn, Cold Spring Harbor Symp. Quant. Biol., in press) or transfer RNA (20) such that they could not attach; (iii) loss, perhaps by permeability changes (33), of a specific cofactor required to initiate host translation; or (iv) some structural change of the host DNA-ribosomes-membrane complex that would make the ribosomes less accessible to host messengers. These alternatives are being examined.

What process in infection is responsible for this early inhibition? Adsorption of DNA-less phage ghosts is sufficient to inhibit host protein synthesis although it produces only a partial inhibition of transcription (R. Fabricant and D. Kennell, in preparation). This finding, along with the fact that the effects on translation-initiation are so immediate, makes it seem likely that the effects on translation observed in the early minutes of infection are caused by the attachment process itself rather than by expression of a phage gene.

It should be noted that in vitro studies of peptide synthesis by extracts from T4-infected cells suggest a second translational control that is dependent on a phage protein. Inhibition of R17 RNA-directed peptide synthesis by extracts from T4-infected cells had been reported by Salser and Gesteland, as cited by Hattman and Hofschneider (13), whereas Smith and Haselkorn (Cold Spring Harbor Symp. Quant. Biol., in press) have observed several new proteins in ribosomes from T4-infected bacteria. In extracts from 12-min T4-infected cells, Hsu et al. (16) reported reduced translational yields from $E$. coli and MS2 RNA but not from T4 RNA. This selective inhibition was found to be due to a heat-labile factor that did not appear until several minutes after infection. Furthermore, it was not made in the presence of chloramphenicol (16). Thus, it seems clear that the very early translational control observed in the present paper results from a different mechanism.

\section{AGKNO WLEDGMENTS}

William Kalchoff, Martin Wice, and Roberta Decker provided excellent assistance in various phases of this work. William Sly, Division of Medical Genetics, gave helpful advice concerning the work with $\lambda$. 
This investigation was supported by Public Health Service grant 2 R01 GM 09830 and Research Career Development Award (1 K04 GM06688-01) from the National Institute of General Medical Sciences and by training grant 5 T1 A1 257-02 from the National Institute of Allergy and Infectious Diseases. Support for the Washington University computing facilities was provided by grant G-22296 from the National Science Foundation.

\section{LITERATURE GITED}

1. Adams, M. H. 1966. Bacteriophages. Interscience Publishers, Inc., New York.

2. Baker, R. F., and C. Yanofsky. 1968. The periodicity of RNA polymerase initiations: a new regulatory feature of transcription. Proc. Nat. Acad. Sci. U.S.A. 60:313-320.

3. Benzer, S. 1953. Induced synthesis of enzymes in bacteria analyzed at the cellular level. Biochim Biophys. Acta 11: 383-395.

4. Bilezikian, J. P., R. O. R. Kaempfer, and B. Magasanik. 1967. Mechanism of tryptophanase induction in Escherichia coli. J. Mol. Biol. 27:495-506.

5. Brown, J. L., S. Kooragian, J. Katze, and I. Zabin. 1966. $\beta$-galactosidase, amino- and carboxyl-terminal studies. J. Biol. Chem. 241:2826-2831.

6. Cohen, S. S. 1948. The synthesis of bacterial viruses. I. The synthesis of nucleic acid and protein in Escherichia coli B infected with $\mathrm{T} 2 \mathrm{r}^{+}$bacteriophage. J. Biol. Chem. 184: 281-293.

7. DiMauro, E., L. Snyder, P. Marino, A. Lamberti, A. Coppo, and G. P. Tocchini-Valentini. 1969. Rifampicin sensitivity of the components of DNA-dependent RNA polymerase. Nature (London) 222:533-537.

8. Gingery, R., and H. Echols. 1967. Mutants of bacteriophage $\lambda$ unable to integrate into the host chromosome. Proc. Nat. Acad. Sci. U.S.A. 58:1507-1514.

9. Godson, G. N. 1967. A technique of rapid lysis for the preparation of Escherichia coli polyribosomes, p. 503-513. In L. Grossman and K. Moldave (ed.), Methods in enzymology, vol. 12, part A. Academic Press Inc., New York.

10. Gottesman, M. E., and M. B. Yarmolinsky. 1968. Integrationnegative mutants of bacteriophage lambda. J. Mol. Biol. 31:487-505.

11. Guarneros, G., and H. Echols. 1970. New mutants of bacteriophage $\lambda$ with a specific defect in excision from the host chromosome. J. Mol. Biol. 47:565-574.

12. Hattman, S., and P. H. Hof schneider. 1967. Interference of bacteriophage T4 in the reproduction of RNA-phage M12. J. Mol. Biol. 29:173-190.

13. Hattman, S., and P. H. Hofschneider. 1968. Influence of T4 on the formation of RNA phage-specific polyribosomes and polymerase. J. Mol. Biol. 35:513-522.

14. Hayward, W. S., and M. H. Green. 1965. Inhibition of Escherichia coli and bacteriophage lambda messenger RNA synthesis by T4. Proc. Nat. Acad. Sci. U.S.A. 54:1675-1678.

15. Hershey, A. D., J. Dixon, and M. Chase. 1953. Nucleic acid economy in bacteria infected with bacteriophage T2. I. Purine and pyrimidine composition. J. Gen. Physiol. 36:777-789.

16. Hsu, W.-T., and S. B. Weiss. 1969. Selective translation of T4 template RNA by ribosomes from T4-infected Escherichia coli. Proc. Nat. Acad. Sci. U.S.A. 64:345-351.

17. Jones, T. H. D., and E. P. Kennedy. 1969. Characterization of the membrane protein component of the lactose transport system of Escherichia coli. J. Biol. Chem. 244:59815987.

18. Joyner, A., L. N. Isaacs, H. Echols, and W. S. Sly. 1966. DNA replication and messenger RNA production after induction of wild-type $\lambda$ bacteriophage and $\lambda$ mutants. J. Mol. Biol. 19:174-186.

19. Kaempfer, R. O. R., and B. Magasanik. 1967. Effect of $T$-even phage on the inducible synthesis of $\beta$-galactosidase in Escherichia coli. J. Mol. Biol. 27:453-468.

20. Kano-Sueoka, T., and N. Sueoka. 1968. Characterization of a modified leucyl-tRNA of Escherichia coli after bacteriophage T4 infection. J. Mol. Biol. 37:475-491.

21. Kennell, D. 1968. Inhibition of host protein synthesis during infection of Escherichia coli by basteriophage T4. I. Continued synthesis of host ribonucleic acid. J. Virol. 2:12621271.

22. Kennell, D. 1968. Titration of the gene sites on DNA by DNA-RNA hybridization. II. The $E$. coli chromosome. J. Mol. Biol. 34:85-103.

23. Kennell, D., and A. Kotoulas. 1967. Magnesium starvation of Aerobacter aerogenes. I. Rates of nucleic acid synthesis and methods for their measurement. J. Bacteriol. 93:345-356.

24. Kennell, D., and A. Kotoulas. 1968. Titration of the gene sites on DNA by DNA-RNA hybridization. I. Problems of measurement. J. Mol. Biol. 34:71-84.

25. Landy, A., and S. Spiegelman. 1968. Exhaustive hybridization and its application to an analysis of the ribonucleic acid synthesized in T4-infected cells. Biochemistry 7:585-591.

26. Levin, A. P., and K. Burton. 1961. Inhibition of enzyme formation following infection of Escherichia coli with phage T2 $\mathrm{r}^{+}$. J. Gen. Microbiol. 25:307-314.

27. Mangiorotti, G., D. Apirion, D. Schlessinger, and L. Silengo. 1968. Biosynthetic precursors of $30 S$ and $50 S$ ribosomal particles in Escherichia coli. Biochemistry 7:456-472.

28. Mangiarotti, G., and D. Schlessinger. 1967. Polyribosome metabolism in Escherichia col. J. Mol. Biol. 29:395-418.

29. Manor, H., D. Goodman, and G. S. Stent. 1969. RNA chain growth rates in Escherichia coli. J. Mol. Biol. 39:1-29.

30. Nomura, M., B. D. Hall, and S. Spiegelman. 1960. Characterization of RNA synthesized in Escherichia coli after bacteriophage T2 infection. J. Mol. Biol. 2:306-326.

31. Rouviere, J., J. Wyngaarden, J. Cantoni, F. Gros, and A. Kepes. 1968. Effect of T4 infection on messenger RNA synthesis in Escherichia coli. Biochim. Biophys. Acta 166:94-114.

32. Sher, I. H., and M. F. Mallette. 1954. The adaptive nature of the formation of lysine decarboxylase in Escherichia coli B. Arch. Biochem. Biophys. 52:331-339.

33. Silver, S., E. Levine, and P. M. Spielman. 1968. Cation fluxes and permeability changes accompanying bacteriophage infection of Escherichia coli. J. Virol. 2:763-771.

34. Steers, E., Jr., C. B. Anfinsen, G. R. Craven, and J. L. Bethune. 1965. Evidence for nonidentical chains in the $\beta$ galactosidase of Escherichia coli. J. Biol. Chem. 240:24782484.

35. Tyler, B., and B. Magasanik. 1969. Molecular basis of transient repression of $\beta$-galactosidase in Escherichia coli. $\mathbf{J}$. Bacteriol. 97:550-556.

36. Visconti, N. 1953. Resistance to lysis from without in bacteria infected with T2 bacteriophage. J. Bacteriol. 66:247-253.

37. Volkin, E., and A. Astrachan. 1956. Phosphorus incorporation in Escherichia coli ribonucleic acid after infection with bacteriophage T2. Virology 2:149-161.

38. Wehrli, W., F. Knusel, K. Schmid, and M. Staehelin. 1968. Interaction of rifampicin with bacterial RNA polymerase. Proc. Nat. Acad. Sci. U.S.A. 61:667-673.

39. Zabin, I. 1963. Proteins of the lactose system. Cold Spring Harbor Symp. Quant. Biol. 28:431-436.

40. Zimmermann, R. A., and C. Levinthal. 1967. Messenger RNA and RNA transcription time. J. Mol. Biol. 30:349370 . 